\title{
ACCUMULATION OF MACRONUTRIENTS IN COWPEA AND WEEDS IN COMPETITION AND UNDER SOIL WATER DEFICIT
}

\author{
ACUMULAÇÃO DE MACRONUTRIENTES EM FEIJÃO-CAUPI E PLANTAS \\ DANINHAS EM COMPETIÇÃO E SOB DÉFICIT HÍDRICO NO SOLO
}

\author{
Fernando Sarmento de OLIVEIRA ${ }^{1}$; Erivanessa Costa Sousa SARMENTO ${ }^{2}$; \\ Jeferson Luiz Dallabona DOMBROSKI ${ }^{3}$; Daniel Valadão SILVA ${ }^{3}$; \\ Claudia Daianny Melo FREITAS ${ }^{4}$; Matheus Freitas SOUZA; \\ Maiara Pinheiro da Silva BORGES ${ }^{6}$; Lindomar Maria da SILVEIRA ${ }^{3}$ \\ 1. Doutorando em Agronomia/Fitotecnia, Universidade Federal Rural do Semi-Árido - UFERSA, Mossoró, RN, Brasil. \\ fernandosarmentho@hotmail.com; 2. Doutoranda em Agronomia/Fitotecnia, Universidade Federal do Ceará - UFC, Fortaleza, CE, \\ Brasil; 3. Professores do Departamento de Ciências Agronômicas e Florestais, UFERSA, Mossoró, RN, Brasil; 4. Mestra em \\ Agronomia/Fitotecnia, UFERSA; 5. Pós-doutorando PNPD-CAPES em Agronomia/Fitotecnia, UFERSA; 6. Mestranda em Ambiente, \\ Tecnologia e Sociedade, UFERSA.
}

\begin{abstract}
The ability of a plant species to succeed in colonization of agroecosystem depends on its efficiency in the use of growth resources even in deficient conditions. The present study aimed to evaluate the effects of competition and water deficit in the soil on the accumulation of macronutrients of Vigna unguiculata L. Walp., Commelina benghalensis L. and Waltheria indica L. The study was conducted in a greenhouse, in randomized block design, with four replications. The treatments were arranged in a $5 \times 2$ factorial, with the first factor corresponding to types of interaction among species ( $V$. unguiculata $+C$. benghalensis; $V$. unguiculata + $W$. indica; $V$. unguiculata in monoculture, $C$. benghalensis in monoculture and $W$. indica in monoculture), and the second of water regimes (irrigated and water deficit). The water deficit differently affects macronutrient content on the species, with decreased of $\mathrm{K}, \mathrm{Ca}$ and $\mathrm{Mg}$ in cowpea, and $\mathrm{N}, \mathrm{P}, \mathrm{K}$ and $\mathrm{Ca}$ in $W$. indica. For $C$. benghalensis, the water deficit does not reduce the macronutrient contents on the plant. The competition between plants intensifies the effects of water deficit only on $C$. benghalensis, with a decreased on the content of all macronutrients studied. Under irrigated conditions, competition between plants was more damaging the weeds compared to cowpea. The $C$. benghalensis specie, free from interference, has a high potential for nutrient extraction under irrigated and water deficit regimes.
\end{abstract}

KEYWORDS: Vigna unguiculata. Commelina benghalensis. Waltheria indica. Interference. Water stress. Mineral nutrition.

\section{INTRODUCTION}

The cowpea (Vigna unguiculata L. Walp.) is one of main food sources of tropical and subtropical regions of world, capable of developing on the most diverse climate and soil conditions. It is one of main components of essential food diet of the poorest populations, has high nutritional value in minerals and proteins, and might be significant source of employment and income (FREIRE FILHO et al., 2011; SOUSA et al., 2015).

In tropical Brazilian conditions, at certain times of year, crop areas are prone to occurrence of periodic droughts, known as "Indian summers", which cause severe socioeconomic losses to rural population, which depends on the production of crops in drought regime for subsistence (SILVA et al., 2010; FREITAS et al., 2017).

The water deficit in soil caused by the "Indian summer" has been one of the main limiting factors for obtaining high productivity, on a regular basis, over the years, influencing almost all the characteristics related to growth and development of cowpea (FREITAS et al., 2014; SOUZA et al., 2017).

Another factor that has contributed to decrease of cowpea productivity is incorrect management of weeds, which can cause up to $90 \%$ decreased of crop production (FREITAS et al., 2009). This is due mainly to competition between the cultivated species and the weeds by vegetable growth resources such as water, light, and nutrients (ZANINE; SANTOS, 2004).

The occurrence of competition with weeds by water can anticipate and/or intensify the deleterious effects of water stress due to low availability of water to plants (CRAINE; DYBZINSKI, 2013). Among these effects, it is possible to emphasize the reduction on the nutrient absorption and of quantities required by the plants 
(GONZALEZ-DUGO; DURAND; GASTAL, 2010; LEÃO; FREIRE; MIRANDA, 2011; DODD et al., 2015). Soil water deficit can reduce the absorption, accumulation, partition and nutrient utilization by plants, due to effect on the decrease of root growth, and by the fact that water is the vehicle through which the mineral nutrients move from the solution of soil to roots of plants, especially when this transport occurs by mass flow and diffusion, that is, all mechanisms of transport of nutrients in soil are affected (BARBER, 1974; MARSCHNER, 1995; HU; SCHMIDHALTER, 2005).

The effects of interspecific competition in mineral nutrition of plant were reported in divers crops, such as coffee (RONCHI et al., 2007), maize (CURY et al., 2012; MELO et al., 2015) and common bean (CURY et al., 2013). However, there is little information on the effects of competition when water is a limiting factor for the species, which reinforces the need for their determinations, aiming to improve the understanding of competition relations between plants, especially when interacting species of plants with different competitive ability. This information is essential for optimizing crop yields in agricultural systems.

Based on these considerations, it was hypothesized that competition between plants for water could aggravate the deleterious effects of water deficit, affecting the absorption and the content of macronutrients. The intensity of these effects might vary between the species involved under water competition and their survival strategies under water deficit conditions.

The objective of present study was to evaluate the effects of competition and water deficit in soil on the macronutrients content of cowpea, Commelina benghalensis, and Waltheria indica .

\section{MATERIAL AND METHODS}

The study was undertaken in a greenhouse, in the municipality of Mossoro-RN. The experimental unit was a plastic vessel with a volumetric capacity of $10 \mathrm{dm}^{-3}$, containing sample of Eutrophic Hapol Plantain (EMBRAPA, 2013), collected in the $0-20 \mathrm{~cm}$ surface layer, with the following characteristics: $\mathrm{pH}$ (water) $=6.5$; organic matter $=1.0$ dag $\mathrm{kg}^{-1} ; \mathrm{P}, \mathrm{K}$ and $\mathrm{Na}=7.2 ; 64.4$ and $3.2 \mathrm{mg} \mathrm{dm}^{-3} ; \mathrm{Ca}, \mathrm{Mg}, \mathrm{Al}, \mathrm{H}+\mathrm{Al}$, and effective CTC $=2.5 ; 1.8 ; 0.0 ; 0.0$ and $4.5 \mathrm{cmol}_{\mathrm{c}} \mathrm{dm}^{-3}$, respectively; sand, silt and clay $=820.0 ; 120.0$ and $50.0 \mathrm{~g} \mathrm{~kg}^{-1}$, respectively; with sand texture. The soil was fertilized based on the recommendations of IPA (2008), with the application in planting of 14.98;
23.66 and $10 \mathrm{mg} \mathrm{dm}^{-3}$ of $\mathrm{P}_{2} \mathrm{O}_{5}, \mathrm{~N}$ and $\mathrm{K}_{2} \mathrm{O}$, respectively.

The experimental design was a randomized block design, with four replications. The treatments were arranged in a $5 \times 2$ factorial scheme, with the first factor consisting of the types of competition between the evaluated species (competition) $[V$. unguiculata $+C$. benghalensis $(\mathrm{V}+\mathrm{C}) ; \quad V$. unguiculata $+W$. indica $(\mathrm{V}+\mathrm{W}) ; V$. unguiculata without competition (V); C. benghalensis without competition (C); and $W$. indica without competition (W)], and the second of the water regimes (irrigated and water deficit).

The cowpea cultivar was BRS Guariba, with an indeterminate growth habit, semi-erect and cycle of 65-70 days (GONÇALVES et al., 2009). W. indica and C. benghalensis seeds were collected in a same cowpea crop area and submitted to procedures to overcome dormancy (seeds subjected to cutting the region opposite to the hilum). The seeds underwent preliminary germination and emergency tests to establish the ideal seeding period for the simultaneous emergence of these species.

Thinning was performed 5 days after plant emergence, leaving the same density of weed and crop (one plant per pot). In cases of co-cultivation of cowpea and weed (competition), cowpea and weeds seeds were sown in the center and border of each experimental unit, respectively.

Irrigations were performed daily to maintain moisture of soil above $70-80 \%$ of the field capacity. The volumes of water applied to each vessel was calculated by the difference between the vessel weight in its field capacity, that was previously determined, and the weight at the end of each day, following a methodology described by Sousa et al. (2015).

When cowpea plants had grown their second definitive leaf trifolium - (phenological stage V4 - 40 days after emergence), the imposition of water regimes (irrigated and water deficit) was initiated. The irrigated treatment plants continued to receive daily irrigation as described, and those on the water deficit treatment had their irrigation totally suspended, so that stress was the result of the gradual exhaustion of the water of soil. The duration of the water deficit was maintained until the rate of assimilation of $\mathrm{CO}_{2}(A)$ of cowpea plants reached values close to zero, which occurred after 11 days of irrigation suspension. From that moment, irrigation was reestablished, maintaining the humidity close to the field capacity. $A$ was measured with the aid of an infrared gas analyzer (IRGA, portable model LI6400, LI-COR Biosciences). 
At 21 days of evaluation, when occurred the recovery of the $A$ of plants submitted to the water deficit treatment, cowpea and weeds were harvested, fractionated them in leaves, stems, and roots. Then the vegetable material was washed in distilled water and then oven dried with forced air circulation at 65 ${ }^{\circ} \mathrm{C}$ until reaching the constant mass. Then, all the dry mass was milled in a Wiley type mill, homogenized and stored in an airtight container. Samples of this material were used to determination of macronutrient contents in the vegetative components of cowpea and weeds. The nitrogen $(\mathrm{N})$ concentrations were determined by Kjeldahl method in the sulfuric acid digestion extract. After nitricperchloric acid digestion, the phosphorus (P) contents were determined by colorimetry and potassium $(\mathrm{K})$ by flame photometry, and calcium (Ca) and magnesium $(\mathrm{Mg})$ by atomic absorption spectrophotometry, following the methodology described by Malavolta, Vitti e Oliveira (1997). From the dry mass of each fraction and their respective nutrient contents, the macronutrient contents was calculated.

For interpretation of the results, the data were submitted to analysis of variance using the $F$ test $(p \leq 0.05)$ and, in the cases of significance, the averages were compared by Tukey's test at 5\% probability level. The statistical software used was SISVAR ${ }^{\circledR}$ 5.6.

\section{RESULTS AND DISCUSSION}

The macronutrient accumulation potential of cowpea and weed free from interference and under irrigated conditions can be verified in Table 1. It was observed that, on average, cowpea has higher macronutrient contents in plant compared to weeds. This result is directly related to higher productivity of dry mass of crop (data not shown) and, coincides with those found by Favero et al. (2000), which indicate that the amount of nutrients accumulated is proportional to amount of biomass produced, varying the absorption efficiency among species.

Table 1. Macronutrient content on the vegetative components of cowpea, Commelina benghalensis and Waltheria indica, cultivated without competition, under irrigated and water deficit regimes

\begin{tabular}{|c|c|c|c|c|c|c|c|c|}
\hline \multirow{3}{*}{ Species } & \multicolumn{8}{|c|}{$N\left(\right.$ mg plant $\left.^{-1}\right)$} \\
\hline & \multicolumn{2}{|c|}{ Leaf } & \multicolumn{2}{|c|}{ Stem } & \multicolumn{2}{|c|}{ Root } & \multicolumn{2}{|c|}{ Total } \\
\hline & WD & Irrigated & WD & Irrigated & WD & Irrigated & WD & Irrigated \\
\hline V & $166.29 \mathrm{aA}$ & $172.99 \mathrm{aA}$ & $80.26 \mathrm{aA}$ & $77.23 \mathrm{bA}$ & $24.43 \mathrm{aB}$ & $46.83 \mathrm{aA}$ & $270.98 \mathrm{aA}$ & $297.04 \mathrm{aA}$ \\
\hline $\mathrm{C}$ & $114.59 \mathrm{bA}$ & $129.20 \mathrm{bA}$ & $63.88 \mathrm{aB}$ & $102.33 \mathrm{aA}$ & $9.92 \mathrm{bA}$ & $6.48 \mathrm{bA}$ & $188.40 \mathrm{bA}$ & $238.0 \mathrm{bA}$ \\
\hline W & $29.43 \mathrm{cB}$ & $101.99 \mathrm{bA}$ & $6.66 \mathrm{bA}$ & $27.40 \mathrm{cA}$ & $3.63 \mathrm{bA}$ & $12.95 \mathrm{bA}$ & $39.72 \mathrm{cB}$ & $142.34 \mathrm{cA}$ \\
\hline \multirow[t]{2}{*}{ CV (\%) } & \multicolumn{2}{|c|}{23.72} & \multicolumn{2}{|c|}{25.31} & \multicolumn{2}{|c|}{25.00} & \multicolumn{2}{|c|}{19.91} \\
\hline & & & & $\mathbf{P}(\mathrm{m}$ & $\left.a n t^{-1}\right)$ & & & \\
\hline \multirow[t]{2}{*}{ Species } & \multicolumn{2}{|c|}{ Leaf } & \multicolumn{2}{|c|}{ Stem } & \multicolumn{2}{|c|}{ Root } & \multicolumn{2}{|c|}{ Total } \\
\hline & WD & Irrigated & WD & Irrigated & WD & Irrigated & WD & Irrigated \\
\hline $\mathrm{V}$ & $40.59 \mathrm{aA}$ & $39.14 \mathrm{aA}$ & $22.34 \mathrm{aA}$ & $25.84 \mathrm{aA}$ & $5.21 \mathrm{aA}$ & $7.28 \mathrm{aA}$ & $68.14 \mathrm{aA}$ & $72.26 \mathrm{aA}$ \\
\hline $\mathrm{C}$ & $15.64 \mathrm{bA}$ & $13.43 \mathrm{bA}$ & $24.39 \mathrm{aB}$ & $32.32 \mathrm{aA}$ & $1.96 \mathrm{bA}$ & $2.51 \mathrm{bA}$ & $41.99 \mathrm{bA}$ & $48.27 \mathrm{bA}$ \\
\hline W & $8.85 \mathrm{bB}$ & $30.41 \mathrm{aA}$ & $3.60 \mathrm{bB}$ & $10.45 \mathrm{bA}$ & $1.64 \mathrm{bA}$ & $3.71 \mathrm{bA}$ & $14.09 \mathrm{cB}$ & $44.57 \mathrm{bA}$ \\
\hline \multirow[t]{2}{*}{ CV (\%) } & \multicolumn{2}{|c|}{24.16} & \multicolumn{2}{|c|}{22.76} & \multicolumn{2}{|c|}{29.80} & \multicolumn{2}{|c|}{23.33} \\
\hline & & & & $K(\mathrm{~m}$ & $\left.\operatorname{ant}^{-1}\right)$ & & & \\
\hline \multirow[t]{2}{*}{ Species } & \multicolumn{2}{|c|}{ Leaf } & \multicolumn{2}{|c|}{ Stem } & \multicolumn{2}{|c|}{ Root } & \multicolumn{2}{|c|}{ Total } \\
\hline & WD & Irrigated & WD & Irrigated & WD & Irrigated & WD & Irrigated \\
\hline V & $98.08 \mathrm{aB}$ & $150.55 \mathrm{aA}$ & 98.94bB & $136.73 \mathrm{bA}$ & $12.14 \mathrm{aB}$ & $25.93 \mathrm{aA}$ & $209.16 \mathrm{bB}$ & $313.21 \mathrm{aA}$ \\
\hline $\mathrm{C}$ & $123.14 \mathrm{aA}$ & $135.32 \mathrm{aA}$ & $134.89 \mathrm{aB}$ & $170.46 \mathrm{aA}$ & $11.40 \mathrm{aA}$ & $7.44 \mathrm{bA}$ & $269.42 \mathrm{aA}$ & $313.22 \mathrm{aA}$ \\
\hline W & $18.91 \mathrm{bB}$ & $72.07 \mathrm{bA}$ & $12.29 \mathrm{cA}$ & $37.93 \mathrm{cA}$ & $3.02 \mathrm{bA}$ & $5.21 \mathrm{bA}$ & $34.22 \mathrm{cB}$ & $115.21 \mathrm{bA}$ \\
\hline \multirow[t]{2}{*}{ CV (\%) } & \multicolumn{2}{|c|}{22.28} & \multicolumn{2}{|c|}{21.14} & \multicolumn{2}{|c|}{20.90} & \multicolumn{2}{|c|}{17.70} \\
\hline & & & & Ca (n & $\left.\operatorname{ant}^{-1}\right)$ & & & \\
\hline Species & & & & & & & & \\
\hline & WD & Irrigated & WD & Irrigated & WD & Irrigated & WD & Irrigated \\
\hline $\mathrm{V}$ & $15.08 \mathrm{aB}$ & $26.04 \mathrm{aA}$ & $1.94 \mathrm{bB}$ & $15.29 \mathrm{aA}$ & $1.32 \mathrm{aB}$ & $4.87 \mathrm{aA}$ & $18.34 \mathrm{aB}$ & $46.19 \mathrm{aA}$ \\
\hline $\mathrm{C}$ & $5.30 \mathrm{bA}$ & $7.77 \mathrm{cA}$ & $16.30 \mathrm{aA}$ & $18.37 \mathrm{aA}$ & $0.83 \mathrm{aA}$ & $1.24 \mathrm{bA}$ & $22.42 \mathrm{aA}$ & $27.38 \mathrm{bA}$ \\
\hline W & $5.31 \mathrm{bB}$ & $14.25 \mathrm{bA}$ & $1.88 \mathrm{bA}$ & $5.17 \mathrm{bA}$ & $0.39 \mathrm{aA}$ & $1.12 \mathrm{bA}$ & $7.57 \mathrm{bB}$ & $20.55 \mathrm{bA}$ \\
\hline CV (\%) & & & & & & & & \\
\hline
\end{tabular}




\begin{tabular}{ccccccccc}
\hline \multirow{2}{*}{ Species } & \multicolumn{9}{c}{ Mg $\left(\mathbf{m g ~ p l a n t}^{\mathbf{1}}\right)$} \\
\cline { 2 - 9 } & \multicolumn{2}{c}{ Leaf } & \multicolumn{2}{c}{ Stem } & \multicolumn{2}{c}{ Root } & \multicolumn{2}{c}{ Total } \\
\cline { 2 - 9 } & WD & Irrigated & WD & Irrigated & WD & Irrigated & WD & Irrigated \\
\hline V & $3.45 \mathrm{aB}$ & $7.01 \mathrm{aA}$ & $2.97 \mathrm{aA}$ & $4.19 \mathrm{aA}$ & $0.63 \mathrm{aA}$ & $0.86 \mathrm{bA}$ & $7.05 \mathrm{aB}$ & $12.06 \mathrm{aA}$ \\
$\mathrm{C}$ & $2.75 \mathrm{aA}$ & $2.85 \mathrm{bA}$ & $4.21 \mathrm{aA}$ & $4.69 \mathrm{aA}$ & $0.66 \mathrm{aA}$ & $0.46 \mathrm{abA}$ & $7.62 \mathrm{aA}$ & $7.99 \mathrm{bA}$ \\
$\mathrm{W}$ & $0.96 \mathrm{bB}$ & $2.42 \mathrm{bA}$ & $0.28 \mathrm{bA}$ & $0.84 \mathrm{bA}$ & $0.05 \mathrm{bA}$ & $0.23 \mathrm{bA}$ & $1.29 \mathrm{bA}$ & $3.50 \mathrm{cA}$ \\
\hline $\mathrm{CV}(\%)$ & \multicolumn{3}{c}{27.69} & \multicolumn{2}{c}{25.39} & 28.48 & & 28.83 \\
\hline
\end{tabular}

$\mathrm{V}=$ Vigna unguiculata $; \mathrm{C}=$ Commelina benghalensis; $\mathrm{W}=$ Waltheria indica $; \mathrm{CV}=$ Coefficient of variation; WD $=$ Water deficit; Averages followed by the same lowercase letter (in the column) and upper case (in the line) do not differ for each variable at the $5 \%$ probability level by Tukey's test.

The nutrients most absorbed by cowpea were $\mathrm{N}, \mathrm{K}$, and $\mathrm{P}$, while the smaller were $\mathrm{Ca}$ and $\mathrm{Mg}$ (Table 1). Fonseca et al. (2010), in a study with cowpea, cultivar BR3-Tracuateua, cultivated in a dystrophic Xanthic Ferralsol in the northern region of Brazil, recorded that the order of macronutrients extraction by the plant was $\mathrm{N}>\mathrm{K}>\mathrm{Ca}>\mathrm{Mg}>\mathrm{P}$.

$C$. benghalensis was high content of macronutrients compared to $W$. indica. It was observed values, in mg plant $^{-1}$, of 238.0 to N, 48.3 to $\mathrm{P}, 313.2$ to $\mathrm{K}, 27.4$ to $\mathrm{Ca}$ and 8.0 to $\mathrm{Mg}$. (Table 1 ). Favero et al. (2000) evaluating the performance of spontaneous and leguminous species, including $C$. benghalensis, also observed that $\mathrm{K}$ and $\mathrm{N}$ are the macronutrients most accumulated by plant, while the smaller was $\mathrm{P}, \mathrm{Ca}$ and $\mathrm{Mg}$.

As for the species $W$. indica, were verified contents of $142.3 ; 44.6 ; 115.2 ; 20.5$ and $3.5 \mathrm{mg}$ plant $^{-1}$ for $\mathrm{N}, \mathrm{P}, \mathrm{K}, \mathrm{Ca}$ and $\mathrm{Mg}$, respectively (Table 1). In a study with weed Sida rhombifolia, belonging to same family of $W$. indica, Bianco, Carvalho e Bianco (2014) observed, at 77 days after emergence, the following decreasing order of macronutrient accumulation: $\mathrm{N}>\mathrm{K}>\mathrm{P}>\mathrm{Ca}>\mathrm{Mg}$.

The difference in total extraction order of $\mathrm{P}$ for cowpea and weeds observed by the other researchers mentioned above, in compared to present study, might be related to forms and degree of availability of phosphorus in experimental area, which vary with the soil and climatic conditions and management of fertilization (FINK et al., 2016).

Analyzing the effect of water regime in species without competition (Table 1). The irrigation suspension decreased the contents of $\mathrm{K}$, $\mathrm{Ca}$ and $\mathrm{Mg}$, in order of 33,60 and $42 \%$, compared to irrigated treatment. On the leaves of cowpea, the water deficit treatment decreased the contents of $\mathrm{K}$, $\mathrm{Ca}$ and $\mathrm{Mg}$, in order of 34,41 and $51 \%$, respectively, compared to irrigated treatment plants. On the stem, this reduction was observed for $\mathrm{K}$ and $\mathrm{Ca}$, in 27 and $87 \%$, respectively. As for the root, the water deficit decreased the contents of $\mathrm{N}, \mathrm{K}$ and $\mathrm{Ca}$, in order of 48,53 and $73 \%$, respectively, compared to irrigated treatment plants (Table 1).
For C. benghalensis specie, the water deficit did not change the total content of macronutrients (Table 1). This result can be related the effect of concentration of these nutrients (MAUAD; CRUSCIOL; GRASSI FILHO, 2011), due to limited growth of species on the water deficient conditions (OLIVEIRA et al., 2018). Another probable explanation is that the rehydration and recovery of water status of plant increased the concentrations of macronutrients to values similar to those measured in irrigated plants. Regarding the organs, the irrigation suspension affected only the contents on the stem, which has reduction for $\mathrm{N}, \mathrm{P}$ and $\mathrm{K}$, in order of 37,24 and $21 \%$, respectively, compared to irrigated treatment. The decreased on the contents in this compartment might be due to change in partition of these nutrients on the plant in response to water deficit, favoring the contents in leaves and roots to detriment of stem. This increase in proportion of N, P and $\mathrm{K}$ translocation to leaves and roots probably is because they are most active organs of plant and the high capacity of remobilization and internal redistribution of these elements (MENGEL; KIRKBY, 1982).

As for $W$. indica, the water deficit decreased the total content of all macronutrients, except for $\mathrm{Mg}$ (Table 1). It was observed reductions of 72, 68, 70 and $63 \%$ for $\mathrm{N}, \mathrm{P}, \mathrm{K}$ and $\mathrm{Ca}$, respectively, compared to irrigated plants. Evaluating the effect in each organ, on the leaves, water deficit decreased the $\mathrm{N}, \mathrm{P}, \mathrm{K}, \mathrm{Ca}$ and $\mathrm{Mg}$ contents, in order of 72,71 , 74,63 and $58 \%$, respectively, compared to irrigated treatment, on the stem, in its turn, the reduction was observed only for $\mathrm{P}(65 \%)$, while on the root, no effect of water deficit was observed. This behavior is a reflection of the root dry mass was not affected by the water deficit (OLIVEIRA et al., 2018).

Possible explanations for reduction of the absorption and content of the macronutrients on the water deficient condition include the limitation of transport of ions to roots, which occur by the diffusion mechanisms $(\mathrm{P}$ and $\mathrm{K})$ and mass flow $(\mathrm{N}$, $\mathrm{Ca}$ and $\mathrm{Mg}$ ), which are processes that depend on the moisture content of the soil (HU; 
SCHMIDHALTER, 2005); the reduction of root growth and its capacity on the macronutrients absorption and translocation, due possibly to process of root suberization (BARBERON et al., 2016) and the reduction of transpiration caused by the stomata closure in plants to minimize water losses (TANGUILIG et al., 1987); and increased mechanical impediment of dry soil for root growth, which limiting the volume of soil explored for nutrient acquisition (GARG, 2003; LEÃO; FREIRE; MIRANDA, 2011). The water deficit can also reduce the dry mass of plant (OLIVEIRA et al., 2018), and thus reduces the demand for nutrients.

For cowpea plants in the irrigated treatment (Table 2), it was observed that, independently of weed, competition decreased only the total $\mathrm{Ca}$ content. This result is due to weeds have a high capacity of extraction of this nutrient, which resulted in a lower nutrient concentration on the soil solution, with a consequent reduction of mass flow, that is the main mechanism of transport of the calcium to roots.

Analyzing the effect of competition in each organ of cowpea, on the leaves, the interference of
$W$. indica increased the content of $\mathrm{P}$, in order of $31 \%$, compared to treatment without competition. Similar results were found by Medeiros et al. (2016), which obtained an increase on the concentration of $\mathrm{P}$ on the leaves in clones of Eucalyptus grandis when submitted to competition with Ipomoea nil species. However, competition with $C$. benghalensis decreased $\mathrm{Ca}$ and $\mathrm{Mg}$ contents in 32 and $23 \%$, respectively. On the stem, the competition decreased only the $\mathrm{Ca}$ content, and the higher effects was under interference of $W$. indica specie, which decreased in approximately $84 \%$ of total content. For the root, competition with $C$. benghalensis increased the $\mathrm{K}$ content, in order of $44 \%$, compared to treatment without competition. The K transport to plant root occurs preferentially by diffusion, owing to a concentration gradient generated on the root surface. Therefore, in competition with cowpea, the $C$. benghalensis specie, owing to its high $\mathrm{K}$ extraction capacity, might have decreased the $\mathrm{K}$ concentration near the roots of crop, and thus favoring the concentration gradient and, consequently, the diffusive flux and the supply of K to cowpea (OLIVEIRA et al., 2010).

Table 2. Macronutrient content on the vegetative components of cowpea in competition with Commelina benghalensis and Waltheria indica, under irrigated and water deficit regimes

\begin{tabular}{|c|c|c|c|c|c|c|c|c|}
\hline \multirow{3}{*}{ Species } & \multicolumn{8}{|c|}{$N\left(\right.$ mg plant $\left.^{-1}\right)$} \\
\hline & \multicolumn{2}{|c|}{ Leaf } & \multicolumn{2}{|c|}{ Stem } & \multicolumn{2}{|c|}{ Root } & \multicolumn{2}{|c|}{ Total } \\
\hline & WD & Irrigated & WD & Irrigated & WD & Irrigated & WD & Irrigated \\
\hline $\mathrm{V}^{1}$ & $166.29 \mathrm{aA}$ & $172.99 \mathrm{aA}$ & $80.26 \mathrm{aA}$ & $77.23 \mathrm{abA}$ & $24.42 \mathrm{aB}$ & $46.83 \mathrm{aA}$ & $270.98 \mathrm{aA}$ & $297.04 \mathrm{aA}$ \\
\hline $\mathrm{V}+\mathrm{C}$ & $176.20 \mathrm{aA}$ & $183.93 \mathrm{aA}$ & $60.55 \mathrm{abA}$ & $57.66 \mathrm{bA}$ & $36.29 \mathrm{aA}$ & $42.62 \mathrm{aA}$ & $273.04 \mathrm{aA}$ & $284.21 \mathrm{aA}$ \\
\hline $\mathrm{V}+\mathrm{W}$ & $172.71 \mathrm{aA}$ & $176.19 \mathrm{aA}$ & $51.79 \mathrm{bB}$ & $83.97 \mathrm{aA}$ & $33.16 \mathrm{aA}$ & $38.09 \mathrm{aA}$ & $257.65 \mathrm{aA}$ & $298.25 \mathrm{aA}$ \\
\hline \multirow[t]{2}{*}{ CV (\%) } & \multicolumn{2}{|c|}{12.82} & \multicolumn{2}{|c|}{21.28} & \multicolumn{2}{|c|}{27.08} & \multicolumn{2}{|c|}{13.34} \\
\hline & & & & $\mathbf{P}(\mathrm{m}$ & $\left.a n t^{-1}\right)$ & & & \\
\hline \multirow[t]{2}{*}{ Species } & \multicolumn{2}{|c|}{ Leaf } & \multicolumn{2}{|c|}{ Stem } & \multicolumn{2}{|c|}{ Root } & \multicolumn{2}{|c|}{ Total } \\
\hline & WD & Irrigated & WD & Irrigated & WD & Irrigated & WD & Irrigated \\
\hline $\mathrm{V}^{1}$ & $40.59 \mathrm{aA}$ & $39.14 \mathrm{bA}$ & $22.34 \mathrm{aA}$ & $25.84 \mathrm{aA}$ & $5.21 \mathrm{bA}$ & $7.28 \mathrm{aA}$ & $68.14 \mathrm{aA}$ & $72.26 \mathrm{aA}$ \\
\hline $\mathrm{V}+\mathrm{C}$ & $39.36 \mathrm{aA}$ & 47.34abA & $21.83 \mathrm{abA}$ & $19.10 \mathrm{aA}$ & $12.24 \mathrm{aA}$ & $7.76 \mathrm{aB}$ & $73.43 \mathrm{aA}$ & $74.19 \mathrm{aA}$ \\
\hline $\mathrm{V}+\mathrm{W}$ & $28.04 \mathrm{bB}$ & $51.08 \mathrm{aA}$ & $14.76 \mathrm{bB}$ & $23.44 \mathrm{aA}$ & $6.63 \mathrm{bB}$ & $11.20 \mathrm{aA}$ & $49.43 \mathrm{bB}$ & $85.73 \mathrm{aA}$ \\
\hline \multirow[t]{2}{*}{ CV (\%) } & \multicolumn{2}{|c|}{17.52} & \multicolumn{2}{|c|}{23.43} & \multicolumn{2}{|c|}{32.82} & \multicolumn{2}{|c|}{14.04} \\
\hline & & & & K (m & $\left.a^{-1}\right)$ & & & \\
\hline \multirow[t]{2}{*}{ Species } & \multicolumn{2}{|c|}{ Leaf } & \multicolumn{2}{|c|}{ Stem } & \multicolumn{2}{|c|}{ Root } & \multicolumn{2}{|c|}{ Total } \\
\hline & WD & Irrigated & WD & Irrigated & WD & Irrigated & WD & Irrigated \\
\hline $\mathrm{V}^{1}$ & $98.08 \mathrm{aB}$ & $150.55 \mathrm{abA}$ & $98.94 \mathrm{aB}$ & $136.73 \mathrm{aA}$ & 12.14abB & $25.93 \mathrm{bA}$ & $209.16 \mathrm{aB}$ & $313.21 \mathrm{aA}$ \\
\hline $\mathrm{V}+\mathrm{C}$ & $112.62 \mathrm{aB}$ & $163.31 \mathrm{aA}$ & $94.40 \mathrm{aB}$ & $133.27 \mathrm{aA}$ & $20.15 \mathrm{aB}$ & $37.40 \mathrm{aA}$ & $227.18 \mathrm{aB}$ & $333.97 \mathrm{aA}$ \\
\hline $\mathrm{V}+\mathrm{W}$ & $110.54 \mathrm{aA}$ & $124.77 \mathrm{bA}$ & $85.41 \mathrm{aA}$ & $112.92 \mathrm{aA}$ & $11.84 \mathrm{bB}$ & $27.85 \mathrm{bA}$ & $207.79 \mathrm{aA}$ & $265.53 \mathrm{aA}$ \\
\hline \multirow[t]{2}{*}{$\mathrm{CV}(\%)$} & \multicolumn{2}{|c|}{19.78} & \multicolumn{2}{|c|}{21.87} & \multicolumn{2}{|c|}{23.71} & & \\
\hline & & & & Ca (n & ant $\left.^{-1}\right)$ & & & \\
\hline Species & & & & & & & & \\
\hline & WD & Irrigated & WD & Irrigated & WD & Irrigated & WD & Irrigated \\
\hline $\mathrm{V}^{1}$ & $15.08 \mathrm{aB}$ & $26.04 \mathrm{aA}$ & $1.94 \mathrm{aB}$ & $15.29 \mathrm{aA}$ & $1.32 \mathrm{bB}$ & $4.87 \mathrm{aA}$ & $18.34 \mathrm{aB}$ & $46.19 \mathrm{aA}$ \\
\hline$V+C$ & $19.21 \mathrm{aA}$ & $17.67 \mathrm{bA}$ & $1.72 \mathrm{aB}$ & $8.83 \mathrm{bA}$ & $2.81 \mathrm{abA}$ & $3.45 \mathrm{aA}$ & $23.73 \mathrm{aA}$ & $29.94 \mathrm{bA}$ \\
\hline $\mathrm{V}+\mathrm{W}$ & $15.61 \mathrm{aA}$ & $19.34 \mathrm{bA}$ & $3.43 \mathrm{aA}$ & $2.49 \mathrm{cA}$ & $4.12 \mathrm{aA}$ & $3.37 \mathrm{aA}$ & $23.16 \mathrm{aA}$ & $25.20 \mathrm{bA}$ \\
\hline CV (\%) & & & & & & & & \\
\hline & & & & $\operatorname{Mg}(\mathrm{n}$ & $\left.\operatorname{lant}^{-1}\right)$ & & & \\
\hline Species & & & & & & & & \\
\hline
\end{tabular}




\begin{tabular}{ccccccccc}
\hline & WD & Irrigated & WD & Irrigated & WD & Irrigated & WD & Irrigated \\
\hline $\mathrm{V}^{1}$ & $3.45 \mathrm{aB}$ & $7.01 \mathrm{aA}$ & $2.97 \mathrm{aA}$ & $4.19 \mathrm{aA}$ & $0.63 \mathrm{aA}$ & $0.86 \mathrm{aA}$ & $7.05 \mathrm{aB}$ & $12.06 \mathrm{aA}$ \\
$\mathrm{V}+\mathrm{C}$ & $4.55 \mathrm{aA}$ & $5.37 \mathrm{bA}$ & $2.52 \mathrm{aA}$ & $3.30 \mathrm{aA}$ & $0.85 \mathrm{aA}$ & $1.83 \mathrm{aA}$ & $7.92 \mathrm{aB}$ & $12.90 \mathrm{aA}$ \\
$\mathrm{V}+\mathrm{W}$ & $4.03 \mathrm{aB}$ & $6.78 \mathrm{abA}$ & $2.23 \mathrm{aA}$ & $3.11 \mathrm{aA}$ & $0.79 \mathrm{aA}$ & $0.77 \mathrm{aA}$ & $7.05 \mathrm{aB}$ & $10.66 \mathrm{aA}$ \\
\hline $\mathrm{CV}(\%)$ & \multicolumn{2}{c}{20.87} & \multicolumn{2}{c}{28.32} & & 17.48 \\
\hline
\end{tabular}

${ }^{1}$ Vigna unguiculata cultivated without the interference of weeds; $\mathrm{V}=$ Vigna unguiculata $; \mathrm{C}=$ Commelina benghalensis; $\mathrm{W}=$ Waltheria indica; $\mathrm{CV}=$ Coefficient of variation; $\mathrm{WD}=$ Water deficit; Averages followed by the same lowercase letter (in the column) and upper case (in the line) do not differ for each variable at the $5 \%$ probability level by Tukey's test.

In the literature, researchers have demonstrated that the effects of weed competition affect macronutrient contents in other crops, such as maize (CURY et al., 2012; MELO et al., 2015) and common bean (CURY et al., 2013; OLIVEIRA et al., 2017).

Regarding the effect of competition on cowpea under water deficit condition (Table 2), it was verified that the competition did not alter the contents of macronutrients in plant, except for $W$. indica, which decreased by $28 \%$ the content total $\mathrm{P}$ in cowpea. This behavior is a reflection of higher competitive capacity by the water of this weed under water deficit conditions (OLIVEIRA et al., 2018). As $P$ is transported to roots mainly by diffusion, the reduction of soil moisture decreased the water film thickness inside the pores, increasing the tortuosity of diffusive path, and decreased the value of diffusion coefficient (OLIVEIRA et al., 2010). Concerning the contents between the organs of plant, it was observed that the competition with $W$. indica decreased the $\mathrm{P}$ content (in $31 \%$ ) on the leaves, and the contents on the stem of $\mathrm{N}$ and $\mathrm{P}$, in order of 35 and $34 \%$, respectively. For the root, competition, except for $C$. benghalensis, which resulted in higher $\mathrm{P}$ content in cowpea, did not affect the macronutrient content. In a study developed by Cury et al. (2013), the authors observed that $C$. benghalensis was the specie with the smaller competition capacity, because it promoted the lower reduction of nutrient content in common bean.

In general, it was verified macronutrient contents in cowpea were affected in a differentiated way in function of water regime and competition with weeds. These results evidenced the variation on the culture regarding the competitive ability and capacity to extract, accumulate and redistribute these nutrients when under these conditions.

For $C$. benghalensis, under irrigated conditions, competition with cowpea decreased the $\mathrm{N}, \mathrm{P}, \mathrm{K}, \mathrm{Ca}$ and $\mathrm{Mg}$ total contents, in order of 81 , $81,85,68$ and $72 \%$, respectively, compared to treatment without competition (Table 3). On the leaves, except for $\mathrm{Ca}$, the competition decreased the contents of all macronutrients, in 78, 70, 83 and $63 \%$ for $\mathrm{N}, \mathrm{P}, \mathrm{K}$ and $\mathrm{Mg}$, respectively. For the stem, this reduction was $91,89,89,85$ and $83 \%$ for $\mathrm{N}, \mathrm{P}$, $\mathrm{K}, \mathrm{Ca}$ and $\mathrm{Mg}$, respectively. On the root, no statistical difference was verified for the competition effect.

Evaluating the competition effect under water deficit conditions in C. benghalensis (Table 3 ), it was verified reductions of $82,82,85,77$ and $80 \%$ for $\mathrm{N}, \mathrm{P}, \mathrm{K}, \mathrm{Ca}$, and $\mathrm{Mg}$, respectively, with the interference of cowpea. These results demonstrated the lowest competitive potential of this species with the culture. In relation to competition effect on the contents between the organs, on the leaves, it was observed a decreased of $\mathrm{N}, \mathrm{P}, \mathrm{K}$ and $\mathrm{Mg}$ contents, in order of $82,84,85$ and $76 \%$, respectively, compared to treatment without competition. As for the stem, the $\mathrm{N}, \mathrm{P}, \mathrm{K}, \mathrm{Ca}$ and $\mathrm{Mg}$ contents were decreased by $84,84,86,94$ and $81 \%$, respectively. On the root, crop interference decreased the $\mathrm{N}, \mathrm{K}$, and $\mathrm{Mg}$ contents in the order of 73,71 and $88 \%$, respectively, compared to plants without competition.

In relation to $W$. indica (Table 4), under irrigated conditions, competition with cowpea decreased the $\mathrm{N}, \mathrm{P}, \mathrm{K}, \mathrm{Ca}$ and $\mathrm{Mg}$ contents on the plant in 89, 91, 90, 96 and 91\%, respectively, compared to plants without competition. As for the organs, on the leaves, competition decreased by more than $90 \%$ the contents of all macronutrients. On the stem, it was verified the decreased of 87,88 , 90,99 and $89 \%$ for $\mathrm{N}, \mathrm{P}, \mathrm{K}, \mathrm{Ca}$ and $\mathrm{Mg}$, respectively. For the root, the competition resulted in estimated losses of $87,84,86,87$ and $92 \%$ in the $\mathrm{N}, \mathrm{P}, \mathrm{K}, \mathrm{Ca}$ and $\mathrm{Mg}$ contents, respectively. 
Table 3. Macronutrient content on the vegetative components of Commelina benghalensis in competition with cowpea under irrigated and water deficit regimes

\begin{tabular}{|c|c|c|c|c|c|c|c|c|}
\hline \multirow{3}{*}{ Species } & \multicolumn{8}{|c|}{$\mathrm{N}\left(\mathrm{mg} \mathrm{plant}^{-1}\right)$} \\
\hline & \multicolumn{2}{|c|}{ Leaf } & \multicolumn{2}{|c|}{ Stem } & \multicolumn{2}{|c|}{ Root } & \multicolumn{2}{|c|}{ Total } \\
\hline & WD & Irrigated & WD & Irrigated & WD & Irrigated & WD & Irrigated \\
\hline $\mathrm{C}^{1}$ & $114.59 \mathrm{aA}$ & $129.19 \mathrm{aA}$ & $63.88 \mathrm{aB}$ & $102.32 \mathrm{aA}$ & $9.92 \mathrm{aA}$ & $6.47 \mathrm{aA}$ & $188.39 \mathrm{aB}$ & $238.0 \mathrm{aA}$ \\
\hline $\mathrm{C}+\mathrm{V}$ & $20.64 \mathrm{bA}$ & $27.92 \mathrm{bA}$ & $10.31 \mathrm{bA}$ & $8.55 \mathrm{bA}$ & $2.66 \mathrm{bB}$ & $8.22 \mathrm{aA}$ & $33.62 \mathrm{bA}$ & $44.69 \mathrm{bA}$ \\
\hline \multirow[t]{2}{*}{ CV (\%) } & \multicolumn{2}{|c|}{24.51} & \multicolumn{2}{|c|}{29.92} & \multicolumn{2}{|c|}{20.27} & \multicolumn{2}{|c|}{19.71} \\
\hline & & & & $\mathbf{P}(\mathbf{m}$ & $\left.n t^{-1}\right)$ & & & \\
\hline \multirow[t]{2}{*}{ Species } & \multicolumn{2}{|c|}{ Leaf } & \multicolumn{2}{|c|}{ Stem } & \multicolumn{2}{|c|}{ Root } & \multicolumn{2}{|c|}{ Total } \\
\hline & WD & Irrigated & WD & Irrigated & WD & Irrigated & WD & Irrigated \\
\hline $\mathrm{C}^{1}$ & $15.63 \mathrm{aA}$ & $13.43 \mathrm{aA}$ & $24.39 \mathrm{aB}$ & $32.32 \mathrm{aA}$ & $1.96 \mathrm{aA}$ & $2.50 \mathrm{aA}$ & $41.99 \mathrm{aA}$ & $48.26 \mathrm{aA}$ \\
\hline $\mathrm{C}+\mathrm{V}$ & $2.45 \mathrm{bA}$ & $4.07 \mathrm{bA}$ & $3.83 \mathrm{bA}$ & $3.56 \mathrm{bA}$ & $1.40 \mathrm{aA}$ & $1.65 \mathrm{aA}$ & $7.68 \mathrm{bA}$ & $9.29 \mathrm{bA}$ \\
\hline \multirow[t]{2}{*}{$\mathrm{CV}(\%)$} & \multicolumn{2}{|c|}{27.72} & \multicolumn{2}{|c|}{25.70} & \multicolumn{2}{|c|}{22.29} & \multicolumn{2}{|c|}{20.11} \\
\hline & & & & $\mathbf{K}(\mathrm{m}$ & $\left.\mathrm{nt}^{-1}\right)$ & & & \\
\hline \multirow[t]{2}{*}{ Species } & \multicolumn{2}{|c|}{ Leaf } & \multicolumn{2}{|c|}{ Stem } & \multicolumn{2}{|c|}{ Root } & \multicolumn{2}{|c|}{ Total } \\
\hline & WD & Irrigated & WD & Irrigated & WD & Irrigated & WD & Irrigated \\
\hline $\mathrm{C}^{1}$ & $123.13 \mathrm{aA}$ & $135.32 \mathrm{aA}$ & $134.89 \mathrm{aB}$ & $170.46 \mathrm{aA}$ & $11.39 \mathrm{aA}$ & $7.44 \mathrm{aA}$ & $269.42 \mathrm{aA}$ & $313.22 \mathrm{aA}$ \\
\hline $\mathrm{C}+\mathrm{V}$ & $17.55 \mathrm{bA}$ & $22.46 \mathrm{bA}$ & $19.0 \mathrm{bA}$ & $18.09 \mathrm{bA}$ & $3.25 \mathrm{bA}$ & $7.04 \mathrm{aA}$ & $39.81 \mathrm{bA}$ & $47.59 \mathrm{bA}$ \\
\hline \multirow[t]{2}{*}{ CV (\%) } & \multicolumn{2}{|c|}{25.25} & \multicolumn{2}{|c|}{22.57} & \multicolumn{2}{|c|}{24.47} & & \\
\hline & & & & $\mathrm{Ca}(\mathrm{m}$ & $\left.a n t^{-1}\right)$ & & & \\
\hline Species & & & & & & & & \\
\hline & WD & Irrigated & WD & Irrigated & WD & Irrigated & WD & Irrigated \\
\hline $\mathrm{C}^{1}$ & $5.29 \mathrm{aA}$ & $7.77 \mathrm{aA}$ & $16.30 \mathrm{aA}$ & $18.36 \mathrm{aA}$ & $0.82 \mathrm{aA}$ & $1.24 \mathrm{aA}$ & $22.42 \mathrm{aA}$ & $27.38 \mathrm{aA}$ \\
\hline $\mathrm{C}+\mathrm{V}$ & $4.12 \mathrm{aA}$ & $5.03 \mathrm{aA}$ & $0.97 \mathrm{bA}$ & $2.73 \mathrm{bA}$ & $0.11 \mathrm{aA}$ & $1.09 \mathrm{aA}$ & $5.20 \mathrm{bA}$ & $8.86 \mathrm{bA}$ \\
\hline CV (\%) & & & & & & & & \\
\hline & & & & $\operatorname{Mg}(\mathrm{n}$ & $\left.\operatorname{ant}^{-1}\right)$ & & & \\
\hline Species & & & & & & & & \\
\hline & WD & Irrigated & WD & Irrigated & WD & Irrigated & WD & Irrigated \\
\hline $\mathrm{C}^{1}$ & $2.74 \mathrm{aA}$ & $2.85 \mathrm{aA}$ & $4.21 \mathrm{aA}$ & $4.69 \mathrm{aA}$ & $0.66 \mathrm{aA}$ & $0.45 \mathrm{aA}$ & $7.61 \mathrm{aA}$ & $7.99 \mathrm{aA}$ \\
\hline $\mathrm{C}+\mathrm{V}$ & $0.64 \mathrm{bA}$ & $1.05 \mathrm{bA}$ & $0.79 \mathrm{bA}$ & $0.77 \mathrm{bA}$ & $0.08 \mathrm{bA}$ & $0.36 \mathrm{aA}$ & $1.51 \mathrm{bA}$ & $2.19 \mathrm{bA}$ \\
\hline CV (\%) & & & & & & & & \\
\hline
\end{tabular}

${ }^{1}$ Commelina benghalensis cultivated without the interference of cowpea; $\mathrm{V}=$ Vigna unguiculata $; \mathrm{C}=$ Commelina benghalensis; $\mathrm{CV}=$ Coefficient of variation; WD= Water deficit; Averages followed by the same lowercase letter (in the column) and upper case (in the line) do not differ for each variable at the $5 \%$ probability level by Tukey's test.

Table 4. Macronutrient content on the vegetative components of Waltheria indica in competition with cowpea under irrigated and water deficit regimes

\begin{tabular}{|c|c|c|c|c|c|c|c|c|}
\hline \multirow{3}{*}{ Species } & \multicolumn{8}{|c|}{$\mathbf{N}\left(\mathrm{mg} \mathrm{plant}^{-1}\right)$} \\
\hline & \multicolumn{2}{|c|}{ Leaf } & \multicolumn{2}{|c|}{ Stem } & \multicolumn{2}{|c|}{ Root } & \multicolumn{2}{|c|}{ Total } \\
\hline & WD & Irrigated & WD & Irrigated & WD & Irrigated & WD & Irrigated \\
\hline $\mathrm{W}^{1}$ & $29.42 \mathrm{aB}$ & $101.98 \mathrm{aA}$ & $6.66 \mathrm{aB}$ & $27.40 \mathrm{aA}$ & $3.62 \mathrm{aB}$ & $12.94 \mathrm{aA}$ & $39.72 \mathrm{aB}$ & $142.34 \mathrm{aA}$ \\
\hline $\mathrm{W}+\mathrm{V}$ & $11.54 \mathrm{aA}$ & $9.79 \mathrm{bA}$ & $3.37 \mathrm{aA}$ & $3.38 \mathrm{bA}$ & $2.62 \mathrm{aA}$ & $1.63 \mathrm{bA}$ & $17.53 \mathrm{aA}$ & $14.81 \mathrm{bA}$ \\
\hline \multirow[t]{2}{*}{ CV (\%) } & \multicolumn{2}{|c|}{28.22} & \multicolumn{2}{|c|}{26.88} & \multicolumn{2}{|c|}{26.03} & \multicolumn{2}{|c|}{24.15} \\
\hline & & & & $\mathbf{P}(\mathrm{m}$ & $\left.n t^{-1}\right)$ & & & \\
\hline \multirow[t]{2}{*}{ Species } & \multicolumn{2}{|c|}{ Leaf } & \multicolumn{2}{|c|}{ Stem } & \multicolumn{2}{|c|}{ Root } & \multicolumn{2}{|c|}{ Total } \\
\hline & WD & Irrigated & WD & Irrigated & WD & Irrigated & WD & Irrigated \\
\hline $\mathrm{W}^{1}$ & $8.85 \mathrm{aB}$ & $30.40 \mathrm{aA}$ & $3.59 \mathrm{aB}$ & $10.45 \mathrm{aA}$ & $1.64 \mathrm{aB}$ & $3.71 \mathrm{aA}$ & $14.09 \mathrm{aB}$ & $44.57 \mathrm{aA}$ \\
\hline $\mathrm{W}+\mathrm{V}$ & $1.28 \mathrm{aA}$ & $1.86 \mathrm{bA}$ & $1.19 \mathrm{aA}$ & $1.26 \mathrm{bA}$ & $0.37 \mathrm{aA}$ & $0.57 \mathrm{bA}$ & $2.86 \mathrm{aA}$ & $3.70 \mathrm{bA}$ \\
\hline \multirow[t]{2}{*}{ CV (\%) } & \multicolumn{2}{|c|}{28.25} & \multicolumn{2}{|c|}{22.52} & \multicolumn{2}{|c|}{29.02} & \multicolumn{2}{|c|}{21.64} \\
\hline & & & & $K(m$ & $\left.\mathrm{nt}^{-1}\right)$ & & & \\
\hline \multirow[t]{2}{*}{ Species } & \multicolumn{2}{|c|}{ Leaf } & \multicolumn{2}{|c|}{ Stem } & \multicolumn{2}{|c|}{ Root } & \multicolumn{2}{|c|}{ Total } \\
\hline & WD & Irrigated & WD & Irrigated & WD & Irrigated & WD & Irrigated \\
\hline $\mathrm{W}^{1}$ & $18.91 \mathrm{aB}$ & $72.07 \mathrm{aA}$ & $12.28 \mathrm{aB}$ & $37.93 \mathrm{aA}$ & $3.02 \mathrm{aA}$ & $5.21 \mathrm{aA}$ & $34.22 \mathrm{aB}$ & $115.21 \mathrm{aA}$ \\
\hline $\mathrm{W}+\mathrm{V}$ & $7.60 \mathrm{aA}$ & $6.58 \mathrm{bA}$ & $2.92 \mathrm{aA}$ & $3.90 \mathrm{bA}$ & $0.92 \mathrm{aA}$ & $0.71 \mathrm{bA}$ & $11.44 \mathrm{aA}$ & $11.20 \mathrm{bA}$ \\
\hline \multirow[t]{2}{*}{ CV (\%) } & \multicolumn{2}{|c|}{29.06} & \multicolumn{2}{|c|}{26.16} & \multicolumn{2}{|c|}{23.84} & \multicolumn{2}{|c|}{26.02} \\
\hline & & & & Ca (n & $\left.\operatorname{lnt}^{-1}\right)$ & & & \\
\hline \multirow[t]{2}{*}{ Species } & \multicolumn{2}{|c|}{ Leaf } & \multicolumn{2}{|c|}{ Stem } & & & & \\
\hline & WD & Irrigated & WD & Irrigated & WD & Irrigated & WD & Irrigated \\
\hline
\end{tabular}




\begin{tabular}{|c|c|c|c|c|c|c|c|c|}
\hline $\mathrm{W}^{1}$ & $5.30 \mathrm{aB}$ & $14.25 \mathrm{aA}$ & $1.87 \mathrm{aB}$ & $5.17 \mathrm{aA}$ & $0.39 \mathrm{aB}$ & $1.12 \mathrm{aA}$ & $7.57 \mathrm{aB}$ & $20.54 \mathrm{aA}$ \\
\hline $\mathrm{W}+\mathrm{V}$ & $1.22 \mathrm{aB}$ & $0.59 \mathrm{bA}$ & $0.09 \mathrm{aA}$ & $0.04 \mathrm{bA}$ & $0.07 \mathrm{aA}$ & $0.15 \mathrm{bA}$ & $1.40 \mathrm{aA}$ & $0.78 \mathrm{bA}$ \\
\hline CV (\%) & \multicolumn{2}{|c|}{26.54} & \multicolumn{2}{|c|}{21.19} & \multicolumn{2}{|c|}{26.19} & \multicolumn{2}{|c|}{23.99} \\
\hline \multirow{3}{*}{ Species } & \multicolumn{8}{|c|}{$\operatorname{Mg}\left(\right.$ mg plant $\left.^{-1}\right)$} \\
\hline & \multicolumn{2}{|c|}{ Leaf } & \multicolumn{2}{|c|}{ Stem } & \multicolumn{2}{|c|}{ Root } & \multicolumn{2}{|c|}{ Total } \\
\hline & WD & Irrigated & WD & Irrigated & WD & Irrigated & WD & Irrigated \\
\hline $\mathrm{W}^{1}$ & $0.96 \mathrm{aB}$ & $2.42 \mathrm{aA}$ & $0.28 \mathrm{aB}$ & $0.84 \mathrm{aA}$ & $0.05 \mathrm{aB}$ & $0.23 \mathrm{aA}$ & $1.29 \mathrm{aB}$ & $3.49 \mathrm{aA}$ \\
\hline $\mathrm{W}+\mathrm{V}$ & $0.42 \mathrm{aA}$ & $0.19 \mathrm{bA}$ & $0.08 \mathrm{aA}$ & $0.09 \mathrm{bA}$ & $0.12 \mathrm{aA}$ & $0.02 \mathrm{bA}$ & $0.63 \mathrm{aA}$ & $0.30 \mathrm{bA}$ \\
\hline $\mathrm{CV}(\%)$ & \multicolumn{2}{|c|}{20.56} & \multicolumn{2}{|c|}{24.92} & \multicolumn{2}{|c|}{23.44} & \multicolumn{2}{|c|}{25.79} \\
\hline
\end{tabular}

${ }^{1}$ Waltheria indica cultivated without the interference of cowpea; $\mathrm{V}=$ Vigna unguiculata; $\mathrm{W}=$ Waltheria indica; $\mathrm{CV}=\mathrm{Coefficient}$ of variation; $\mathrm{WD}=$ Water deficit; Averages followed by the same lowercase letter (in the column) and upper case (in the line) do not differ for each variable at the $5 \%$ probability level by Tukey's test.

Despite being considered good competitors, weeds were also negatively affected by effects of crop competition, with decreased macronutrient content. Bianco, Carvalho e Bianco (2014), evaluating the mineral nutrition of the weed Sida rhombifolia, recorded that, individually, a plant does not present high competition potential for nutrients, however, the authors comment that in cases if dense populations are established, the extraction of nutrients from the soil can be very intense, and affecting the growth and productivity of agricultural crops. This fact occurs because the weed effect is not caused by its individual competitive capacity, but rather by the total population of the weed community (VILÀ; WILLIAMSON; LONSDALE, 2004; BIANCHI; FLECK; LAMEGO, 2006).

However, when analyzing the effects of competition of the cowpea on the $W$. indica specie under water deficit conditions (Table 4), it was observed that the competition did not affect the total macronutrients contents. In the same way, the competition did not alter the content of macronutrients in any of organs on the plant. This result demonstrates the high competitive capacity of this species by nutrients under water deficient conditions. This behavior is mainly owing to adaptation mechanism to water deficit of this species, which invests on the growth of its roots and the water extraction from the soil in very negative water potentials (OLIVEIRA et al., 2018) and, thus, maintains the absorption and nutrients accumulation on the plant.

\section{CONCLUSIONS}

The water deficit differently affects macronutrient content on the species, with decreased of $\mathrm{K}, \mathrm{Ca}$ and $\mathrm{Mg}$ in cowpea, and $\mathrm{N}, \mathrm{P}, \mathrm{K}$ and $\mathrm{Ca}$ in $W$. indica. For $C$. benghalensis, the water deficit does not reduce the macronutrient contents on the plant.

The competition between plants intensifies the effects of water deficit only on $C$. benghalensis, with a decreased on the content of all macronutrients studied.

Under irrigated conditions, competition between plants was more damaging the weeds compared to cowpea.

The $C$. benghalensis specie, free from interference, has a high potential for nutrient extraction under irrigated and water deficit regimes.

\section{ACKNOWLEDGMENTS}

The Conselho Nacional de Desenvolvimento Científico e Tecnológico - Brasil (CNPq), for the financial support to this research.

RESUMO: A capacidade de uma espécie vegetal para ter sucesso na colonização do agroecossistema depende da sua eficiência na utilização dos recursos de crescimento mesmo em condições deficientes. Objetivou-se avaliar os efeitos da competição e déficit hídrico no solo no conteúdo de macronutrientes de feijão-caupi (Vigna unguiculata L. Walp.), trapoeraba (Commelina benghalensis L.) e malva-branca (Waltheria indica L.). Foi conduzido estudo em casa de vegetação, em delineamento em blocos casualizado, com quatro repetições. Os tratamentos foram arranjados em fatorial $5 \times 2$, com o primeiro fator correspondente aos arranjos de competição entre as espécies ( $V$. unguiculata $+C$. benghalensis; $V$. unguiculata $+W$. indica; $V$. unguiculata em monocultivo; $C$. benghalensis em monocultivo e $W$. indica em monocultivo), e o segundo dos regimes hídricos (irrigado e déficit hídrico). O déficit hídrico afeta de forma diferenciada o conteúdo de macronutrientes nas espécies, com redução de $\mathrm{K}, \mathrm{Ca}$ e $\mathrm{Mg}$ no feijão-caupi, e N, P, K e Ca em $W$. indica. Para C. benghalensis, o déficit hídrico não reduz os conteúdos de macronutrientes na planta. A competição entre plantas intensifica os efeitos do déficit hídrico apenas em $C$. benghalensis, com redução do conteúdo de todos os macronutrientes 
estudados. Em condições irrigadas, a competição entre plantas foi mais prejudicial as plantas daninhas do que o feijão-caupi. A espécie C. benghalensis, livre de interferência, apresenta elevado potencial de extração de nutrientes sob regimes irrigado e de déficit hídrico.

PALAVRAS-CHAVE: Vigna unguiculata. Commelina benghalensis. Waltheria indica. Interferência. Estresse hídrico. Nutrição mineral.

\section{REFERENCES}

BARBER, S. A. Influence of the plant root on ion movement in soil. In: CARSON, E. W. (org.). The plant root and its environment. Charlottesville: University Press of Virginia, 1974. p. 524-564.

BARBERON, M.; VERMEER, J. E. M.; BELLIS, D.; WANG, P.; NASEER, S.; ANDERSEN, T. G.; HUMBEL, B. M.; NAWRATH, C.; TAKANO, J.; SAL, D. E.; GELDNER, N. Adaptation of Root Function by Nutrient-Induced Plasticity of Endodermal Differentiation. Cell, v. 164, n. 3, p.447-459, 2016. https://doi.org/10.1016/j.cell.2015.12.021

BIANCO, S.; CARVALHO, L. B.; BIANCO, M. S. Crescimento e nutrição mineral de Sida rhombifolia. Planta Daninha, Viçosa, v. 32, n. 2, p. 311-317, 2014. https://doi.org/10.1590/S0100-83582014000200008

BIANCHI, M. A.; FLECK, N. G.; LAMEGO, F. P. Proporção entre plantas de soja e plantas competidoras e as relações de interferência mútua. Ciência Rural, Santa Maria, v. 36, n. 5, p.1380-1387, 2006. https://doi.org/10.1590/S0103-84782006000500006

CRAINE, J. M.; DYBZINSKI, R. Mechanisms of plant competition for nutrients, water and light. Functional Ecology, London, v. 27, p. 833-840, 2013. https://doi.org/10.1111/1365-2435.12081

CURY, J. P.; SANTOS, J. B.; SILVA, E. B.; BYRRO, E. C. M.; BRAGA, R. R.; CARVALHO, F. P.; VALADÃO SILVA, D. Acúmulo e partição de nutrientes de cultivares de milho em competição com plantas daninhas. Planta daninha, Viçosa, v. 30, p. 287-296, 2012. https://doi.org/10.1590/S010083582012000200007

CURY, J. P. SANTOS, J. B.; SILVA, E. B.; BRAGA, R. R.; CARVALHO, F. P.; VALADÃO SILVA, D.; BYRRO, E. C. M. Eficiência nutricional de cultivares de feijão em competição com plantas daninhas. Planta Daninha, Viçosa, v. 31, n. 1, p. 79-88, 2013. https://doi.org/10.1590/S0100-83582013000100009

DODD, I. C.; PUÉRTOLAS, J.; HUBER, K.; PÉREZ-PÉREZ, J. G.; WRIGHT, H. R.; BLACKWELL, M. S. A. The importance of soil drying and re-wetting in crop phytohormonal and nutritional responses to deficit irrigation. Journal of Experimental Botany, Lancaster, v. 66, n. 8, p. 2239-2252, 2015.

https://doi.org/10.1093/jxb/eru532

EMBRAPA - Empresa Brasileira de Pesquisa Agropecuária. Sistema brasileiro de classificação de solos. 3 ed. rev. ampl. Brasília-DF: Embrapa, 2013. 353p.

FAVERO, C.; JUCKSCH, I.; COSTA, L. M.; ALVARENGA, R. C.; NEVES, J. C. L. Crescimento e acúmulo de nutrientes por plantas espontâneas e por leguminosas utilizadas para adubação verde. Revista Brasileira de Ciência do Solo, Viçosa, v. 24, n. 1, p. 171-177, 2000. https://doi.org/10.1590/S0100-06832000000100019

FINK, J. R., INDA, A. V., BAVARESCO, J., BARRÓN, V., TORRENT, J.; BAYER, C. Adsorption and desorption of phosphorus in subtropical soils as affected by management system and mineralogy. Soil And Tillage Research, Amsterdam, v.155, p. 62-68, 2016. https://doi.org/10.1016/j.still.2015.07.017

FONSECA, M. R.; FERNANDES, A. R.; SILVA, G. R.; BRASIL, E. D. Teor e acúmulo de nutrientes por plantas de feijão-caupi em função do fósforo e da saturação por bases. Revista de Ciências Agrárias, Belém, v. 53, n. 2, p. 195-205, 2010. https://doi.org/10.4322/rca.2011.028 
FREIRE FILHO, F. R.; RIBEIRO, V. Q.; ROCHA, M. M.; SILVA, K. J. D.; NOGUEIRA, M. S. R.; RODRIGUES, E. V. Feijão-caupi no Brasil: produção, melhoramento genético, avanços e desafios. Teresina: Embrapa Meio-Norte, 2011.

FREITAS, F. C. L.; MEDEIROS, V. F. L. P.; GRANGEIRO, L.C.; SILVA, M. G. O.; NASCIMENTO, P. G. M. L.; NUNES, G. H. Interferência de plantas daninhas na cultura do feijão-caupi. Planta Daninha, Viçosa, v. 27, n. 2, p. 241-247, 2009. https://doi.org/10.1590/S0100-83582009000200005

FREITAS, R. M. O.; DOMBROSKI, J. L. D.; FREITAS, F. C. L.; NOGUEIRA, N. W.; PINTO, J. R. S. Crescimento de feijão-caupi sob efeito de veranico nos sistemas de plantio direto e convencional. Bioscience Journal, Uberlândia, v. 30, n. 2, p. 393-401, 2014.

FREITAS, R. M. O.; DOMBROSKI, J. L. D.; FREITAS, F. C. L.; NOGUEIRA, N. W.; PINTO, J. R. S. Physiological responses of cowpea under water stress and rewatering in no-tillage and conventional tillage systems. Revista Caatinga, Mossoró, v.30, n.3, p.559-567, 2017. https://doi.org/10.1590/1983$21252017 \mathrm{v} 30 \mathrm{n} 303 \mathrm{rc}$

GARG, B. K. Nutrient uptake and management under drought: nutrient-moisture interaction. Current Agriculture, Bhopal, v. 27, p. 1-8, 2003.

GONÇALVES, J. R. P.; FONTES, J. R. A.; DIAS, M. C.; ROCHA, M. S.; FREIRE FILHO, F. R. BRS Guariba: nova cultivar de feijão-caupi para o estado do Amazonas. Manaus: Embrapa Amazônia Ocidental, 2009. 4p.

GONZALEZ-DUGO, V.; DURAND, J.; GASTAL, F. Water deficit and nitrogen nutrition of crops. A review. Agronomy Sustainable Development, Baghdad, v. 30, n. 3, p. 529-544, 2010. https://doi.org/10.1051/agro/2009059

HU, Y.; SCHMIDHALTER, U. Drought and salinity: A comparison of their effects on mineral nutrition of plants. Journal of Plant Nutrition and Soil Science, v. 168, n. 4, p.541-549, 2005.

https://doi.org/10.1002/jpln.200420516

IPA - Empresa Pernambucana de Pesquisa Agropecuária. Recomendações de Adubação para o Estado de Pernambuco (2 ${ }^{\mathrm{a}}$ aproximação). 2 ed. Recife: IPA, 2008. 198p.

LEÃO, D. A. S.; FREIRE, A. L. O.; MIRANDA, J. R. P. Estado nutricional de sorgo cultivado sob estresse hídrico e adubação fosfatada. Revista Pesquisa Agropecuária Tropical, Goiânia, v. 41, n. 1, p. 74-79, 2011. https://doi.org/10.5216/pat.v41i1.8285

MALAVOLTA, E; VITTI, G. C.; OLIVEIRA, S. A. Avaliação do estado nutricional das plantas: princípios e aplicações. Piracicaba: Associação Brasileira para Pesquisa da Potassa e do Fosfato, 1997.

MARSCHNER, H. Mineral nutrition of higher plants. 2. ed. Londres, Academic Press, 1995. p. 347-364.

MAUAD, M.; CRUSCIOL, C. A. C.; GRASSI FILHO, H. Produção de massa seca e nutrição de cultivares de arroz de terras altas sob condição de déficit hídrico e adubação silicatada. Semina: Ciências Agrárias, Londrina, v. 32, n. 3, p.939-948, 2011. https://doi.org/10.5433/1679-0359.2011v32n3p939

MEDEIROS, W. N., MELO, C. A. D., TIBURCIO, R. A. S., SILVA, G. S., MACHADO, A. F. L., SANTOS, L. D. T.; FERREIRA, F. A. Crescimento inicial e concentração de nutrientes em clones de Eucalyptus urophylla $\mathrm{x}$ Eucalyptus grandis sob interferência de plantas daninhas. Ciência Florestal, Santa Maria, v. 26, n. 1, p. 147-157, 2016. https://doi.org/10.5902/1980509821099 
MELO, C. A. D.; GUIMARÃES, F. A. R.; GONÇALVES, V. A.; BENEVENUTE, S. S.; FERREIRA, G. L.; FERREIRA, L. R.; FERREIRA, F. A. Acúmulo de macronutrientes por plantas daninhas e de milho cultivadas em convivência em solo com diferentes manejos de fertilidade. Semina: Ciências Agrárias, Londrina, v. 36, n. 2, p. 669-682, 2015. https://doi.org/10.5433/1679-0359.2015v36n2p669

MENGEL, K.; KIRKBY, E.A. Principles of plant nutrition. 3. ed. Berna, International Potash Institute, 1982. $655 \mathrm{p}$.

OLIVEIRA, E. M. M.; RUIZ, H. A.; ALVAREZ, V.; HUGO, V.; FERREIRA, P. A.; COSTA, F. O.; ALMEIDA, I. C. C. Nutrient supply by mass flow and diffusion to maize plants in response to soil aggregate size and water potential. Revista Brasileira de Ciência do Solo, Viçosa, v. 34, n. 2, p. 317-328, 2010. https://doi.org/10.1590/S0100-06832010000200005

OLIVEIRA, L. S. G.; DALVI, L. P.; ALTOÉ, S. C.; ROCHA, L. J. F. N.; OLIVEIRA, F. L. La competencia de la maleza (Commelina diffusa L.) puede afectar las características agronómicas y el contenido mineral de los granos de frijol. Ciencia e Investigación Agraria, Santiago, v. 44, n. 2, p.121-126, 2017. https://doi.org/10.7764/rcia.v44i2.1590

OLIVEIRA, F. S.; GAMA, D. R. S.; DOMBROSKI, J. L. D.; SILVA, D. V.; OLIVEIRA FILHO, F. S.; RAMALHO NETA, T.; SOUZA, M. M. Competition between cowpea and weeds for water: Effect on plants growth. Revista Brasileira de Ciências Agrárias - Brazilian Journal Of Agricultural Sciences, Recife, v. 13, n. 1, p. 1-7, 2018. https://doi.org/10.5039/agraria.v13i1a5507

RONCHI, C. P.; TERRA, A. A.; SILVA, A. A. Growth and nutrient concentration in coffee root system under weed species competition. Planta Daninha, Viçosa, v. 25, n. 4, p.679-687, 2007.

https://doi.org/10.1590/S0100-83582007000400004

SILVA, V. P. R.; AZEVEDO, P. V.; BRITO, R. S.; CAMPOS, J. H. B. C. Evaluating the urban climate of a typically tropical city of northeastern Brazil. Environmental Monitoring and Assessment, v. 161, n. 1-4, p. 45-59, 2010. https://doi.org/10.1007/s10661-008-0726-3

SOUSA, C. C. M.; PEDROSA, E. M. R.; ROLIM, M. M.; OLIVEIRA FILHO, R. A.; SOUZA, M. A. L. M.; PEREIRA FILHO, J. V. Crescimento e respostas enzimáticas do feijoeiro caupi sob estresse hídrico e nematoide de galhas. Revista Brasileira de Engenharia Agrícola e Ambiental, Campina Grande, v. 19, n. 2, p. 113-118, 2015. https://doi.org/10.1590/1807-1929/agriambi.v19n2p113-118

SOUZA, P. J. O. P.; FARIAS, V. D. S.; LIMA, M. J. A.; RAMOS, T. F.; SOUSA, A. M. L. Cowpea leaf area, biomass production and productivity under different water regimes in Castanhal, Pará, Brazil. Revista

Caatinga, Mossoró, v. 30, n. 3, p. 748-759, 2017. https://doi.org/10.1590/1983-21252017v30n323rc

TANGUILIG, V. C.; YAMBAO, E. B.; TOOLE, J. C. O.; DATTA, S. K. Water stress effects on leaf elongation, leaf water potential, transpiration, and nutrient uptake of rice, maize, and soybean. Plant and Soil, Dordrecht, v. 103, n. 2, p. 155-168, 1987. https://doi.org/10.1007/BF02370385

VILÀ, M.; WILLIAMSON, M.; LONSDALE, M. Competition experiments on alien weeds with crops: lessons for measuring plant invasion impact?. Biological Invasions, Knoxville, v. 6, n. 1, p. 59-69, 2004. https://doi.org/10.1023/B:BINV.0000010122.77024.8a

ZANINE, A. M.; SANTOS, E. D. Competição entre espécies de plantas - uma revisão. Revista da FZVA, Uruguaiana, v. 11, n. 1, p. 103-122, 2004. 